\title{
STRATEGI PEMBELAJARAN PENDIDIKAN AGAMA ISLAM ANTISIPASI KRISIS AKHLAK PESERTA DIDIK PADA SMA NEGERI DI PALOPO
}

\author{
Syamsu S. \\ Institut Agama Islam Negeri (IAIN) Palopo \\ syam1954783@gmail.com
}

\begin{abstract}
This research aims to explore the implications of applied learning strategies of Islamic education teachers for anticipation moral crisis of students in high schools in Palopo. This type of research is quantitative descriptive model with ex post facto. The subject of this research is Islamic education teachers at six high schools in Palopo. Data collection techniques used observation, interviews, and questionnaires. Data analyze technique used statistic and qualitative methods. The results showed that: 1) Islamic education teachers in high schools in Palopo often apply various learning strategies; 2), The efforts of Islamic education teachers in high schools in Palopo often attempt to use morale education to anticipate morale crisis of students, to optimize teachers' role and morale learning, 3) Learning strategies applied by Islamic education teachers are not significant to give implications towards the anticipated efforts of the high school students' morale crisis in Palopo.
\end{abstract}

Keywords: Learning Strategy, Moral Crisis

\begin{abstract}
Abstrak
Penelitian ini bertujuan untuk mengungkap implikasi strategi pembelajaran yang diterapkan guru PAI terhadap upaya antisipasi krisis akblak peserta didik pada SMA Negeri di Palopo. Jenis penelitian ini adalah kuantitatif deskriptif dengan model expost facto. Subjek penelitian adalah guru PAI pada enam SMA Negeri di Kota Palopo. Teknik pengumpulan data: observasi, wawancara, dan angket. Analisis data menggunakan teknik statistik deskriptif. Hasil penelitian menunjukkan: 1) Guru PAI pada SMA Negeri di Palopo sering menerapkan strategi pembelajaran secara variatif; 2) Guru PAI pada SMA Negeri di Palopo sangat sering melakukan upaya antisipasi krisis akblak peserta didik melalui pendidikan akblak, mengatasi krisis akblak, optimalisasi peran guru, dan pembelajaran akblak; 3) Strategi pembelajaran yang diterapkan guru PAI tidak signifikan berimplikasi terhadap upaya antisipasi krisis akblak peserta didik pada SMA Negeri di Palopo
\end{abstract}

Kata kunci: Strategi Pembelajaran, Krisis Akhlak

Permalink/DOI: http://dx.doi.org/10.18326/infsl3.v9i2.373-396 


\section{Pendahuluan}

Pembentukan manusia yang berakhlak mulia merupakan kegiatan yang mesti melewati proses pembentukan kepribadian yang tidak bisa tumbuh dengan tiba-tiba. Di dalam proses pembentukan kepribadian itulah diperlukan landasan, strategi, wacana, dan metode yang tepat. Membentuk manusia yang berakhlaik mulia adalah salah satu dari aspek tujuan pendidikan nasional (UU Nomor 20 Tahun 2003 Bab II Pasal 3). Begitu pula membentuk peserta didik memahami, menghayati, dan mengamalkan nilai-nilai agama adalah tujuan pendidikan agama (PP No. 55 Tahun 2007 Bab II Pasal 2 ayat 2). UU dan PP tersebut menjadi pijakan dasar penyelenggaraan pendidikan agama di sekolah guna mentransformasi pengetahuan agama kepada peserta didik, diinternalisasikan, dan menjadi kepribadiannya dalam kehidupan sehari-hari.

Teori pendidikan dan pengajaran dimajukan Nata dan Baki. Nata (2009: 29), pendidikan adalah upaya memengaruhi peserta didik agar mau mengubah pola pikir, tindakan, dan perbuatannya sesuai dengan tujuan yang ditetapkan. Baki (2014: 96) merumuskan, pengajaran sebagai suatu sistem menyangkut komponen, tujuan, bahan, metode, dan alat serta penilaian.

Landasan filosofis dan teoretis tersebut meniscayakan penyelenggaraan pendidikan agama di sekolah dalam bingkai pendidikan nasional dan untuk mencapai tujuan pendidikan nasional. Pada konteks inilah guru PAI dituntut mendesain sistem pembelajarannya yang secara konkret dapat membentuk akhlak mulia peserta didik baik di sekolah maupun di luar sekolah. Pembelajaran PAI di sekolah tidak sekedar terkonsentrasi pada persoalan teoretis yang bersifat kognitif semata, melainkan juga mampu mengubahnya menjadi nilai-nilai yang terinternalisasi dalam diri peserta didik sehingga dapat berperilaku secara konkret-agamis dalam kehidupan praktis sehari-hari.

Munculnya berbagai gejala kemerosotan akhlak yang terjadi di masyarakat sebagai ekses era modernisasi, kini menimpa sebagian kalangan remaja yang amat mengkhawatirkan. Mereka sudah banyak terlibat dalam tawuran, penggunaan obat terlarang, minuman keras, penodongan, pelanggaran seksual, dan perbuatan 
kriminal (Nata, 2010: 218). Perilaku menyimpang itu semakin memprihatinkan, saat ini menjadi isu krisis akhlak yang mencederai tatanan kehidupan masyarakat. Dalam konteks kehidupan di sekolah, perilaku menyimpang seperti perkelahian antarpelajar, pergaulan bebas, menyalahi aturan berpakain, menyalahi etika berlalu lintas, kecurangan dalam ujian, kurang menghargai guru atau menghargainya hanya di sekolah, membolos, panjat pagar, penyalahgunaan handphone, merokok dalam lingkungan sekolah, saat ini menjadi isu krisis akhlak dan menjadi persoalan bagi penyelenggaraan pendidikan di sekolah.

Penelitian awal pada beberapa guru SMA Negeri di Palopo diperoleh data bahwa pembelajaran PAI di sekolah dilaksanakan sesuai program Silabus dan Rencana Pelaksanaan Pembelajaran (RPP), dan hasil evaluasi belajar peserta didik kategori baik. Indikatornya adalah nilai hasil belajar pelajaran Pendidikan Agama Islam semester gasal tahun pelajaran 2013/2014 rata-rata 87,47 melampaui nilai standar KKM yaitu 75 . Hasil belajar ini menunjukkan bahwa kompetensi yang akan dicapai dalam proses pembelajaran berhasil.

Pada tataran realitas, ketika mencermati pergaulan peserta didik SMA Negeri di Palopo, perilaku mereka cenderung kontradiksi dengan prestasi belajar yang dicapai. Ada indikasi peserta didik kurang menginternalisasikan pengetahuan agama yang mereka pahami dalam kehidupan praktis sehari-hari baik di sekolah maupun di luar sekolah. Perilaku mereka menyimpang dari nilai-nilai ajaran Islam, akhlak tidak terpuji sebagaimana disebutkan di atas masih biasa dilakukan di sekolah. Oleh karena itu, memberikan perhatian pada upaya antisipasi krisis akhlak lebih diutamakan dibanding upaya mengatasinya.

Pada kondisi seperti ini guru PAI pada SMA Negeri di Palopo dituntut untuk tanggap dan kreatif dalam memilih dan menerapkan strategi pembelajaran yang dapat memotivasi aktivitas belajar, menumbuhkan semangat intenalisasi nilai-nilai islami (afektif) ke dalam dirinya terhadap pengetahuan agama (kognitif) yang dipahaminya, untuk kemudian diimplementasikan dalam bentuk amaliah secara nyata (psikomotor) sehingga pengetahuan agama 
yang dipahaminya berfungsi untuk mengantisipasi terjadinya krisis akhlak.

Berdasarkan uraian di atas maka penulis tertarik untuk melakukan penelitian terhadap guru PAI pada SMA Negeri di Palopo tentang strategi pembelajaran yang diterapkan sebagai upaya mengantisipasi krisis akhlak peserta didik. Oleh karena itu permasalahan penelitian ini dirumuskan sebagai berikut: 1) Bagaimana penerapan strategi pembelajaran guru PAI pada SMA Negeri di Palopo? 2) Bagaimana upaya guru PAI dalam mengantisipasi krisis akhlak peserta didik pada SMA Negeri di Palopo? dan 3) Apakah strategi pembelajaran yang diterapkan guru PAI berimplikasi terhadap upaya antisipasi krisis akhlak peserta didik pada SMA Negeri di Palopo?

\section{Definisi Strategi Pembelajaran}

Istilah strategi pada mulanya digunakan dalam dunia militer, diartikan sebagai cara penggunaan seluruh kekuatan militer untuk memenangkan suatu peperangan (Sanjaya, 2008: 293). Istilah strategi kemudian berkembang dan digunakan dalam bidang-bidang ilmu lainnya termasuk ilmu pendidikan. Djamarah (2006: 52) mengartikan strategi sebagai suatu garis-garis besar haluan untuk bertindak dalam usaha mencapai sasaran yang telah ditentukan. Arifin dalam Pimay (205: 50) mengartikan strategi sebagai segala cara dan daya untuk menghadapi sasaran tertentu dalam kondisi tertentu agar memeroleh hasil yang diharapkan secara maksimal. Pembelajaraan berarti upaya membelajarkan peserta didik (Dengeng dalam Wena, 2011: 2) Perpaduan kata strategi dan pembelajaran menjadi strategi pembelajaran berarti langkah-langkah yang terencana dan bermakna luas dalam menggerakkan seseorang agar dengan kemampuan dan kemauannya sendiri dapat melakukan kegiatan yang berhubungan dengan belajar (Nata, 2009: 209).

Definisi strategi pembelajaran dikemukakan antara lain oleh Sabri dan Wena. Sabri (2005: 1) menyatakatan, strategi pembelajaran adalah upaya guru dalam menciptakan suatu sistem lingkungan belajar yang memungkinkan terjadinya proses pembelajaran, agar tujuan pembelajaran yang telah dirumuskan dapat tercapai dan 
efektif. Wena (2011: 2) menyatakan, strategi pembelajaran berarti cara dan seni untuk menggunakan semua sumber belajar dalam upaya membelajarkan peserta didik.

Strategi pembelajaran menjadi salah satu barometer profesionalis seorang guru mengingat proses pembelajaran merupakan proses komunikasi multiarah antarpeserta didik, guru, dan lingkungan belajar. Karena itu, strategi pembelajaran menjadi pedoman bertindak secara sistematis dalam pelaksanaan pembelajaran sehingga materi pelajaran dengan mudah dapat dipahami.

Penelitian terdahulu yang mengkaji tentang strategi pembelajaran, antara lain Sarifa Suhra (2014), hasil penelitiannya menandaskan strategi yang diterapkan guru PAI pada SMA Negeri 1 Watampone efektif menghidupkan karakter yang baik di sekolah adalah menerapkan model pembelajaran yang bervariasi, keteladanan, pembiasaan, pembinaan disiplin, hadiah dan hukuman, pembelajaran kontekstual, bermain peran, dan pembelajaran partisipatif. Selain itu, melakukan pembinaan peserta didik secara intensif melalui organisasi Rohis, dan penggunaan RPP yang memuat nilai-nilai karakter. Rusman (2010: 380), dalam penelitiannya mendeskripsikan penyebab rendahnya kualitas pendidikan di Indonesia karena praktik pembelajaran pada umumnya dilakukan secara konvensional, komunikasi verbal sebagai satu-satunya sumber informasi, bagaimana peserta didik mau belajar kurang diperhatikan, akibatnya pembelajaran tidak banyak memberikan kontribusi bagi peningkatan mutu proses dan hasil pembelajaran.

Beberapa riset lainnya berkaitan dengan strategi pembelajaran, 1) Nata (2009: 210) Perspektif Islam tentang Strategi Pembelajaran; 2) Yahiji (2011) Strategi Pembelajaran dalam Meningkatkan Pemahaman Kitab Kuning di Pondok Pesantren Salafiyah Syafi'iyah Randangan Provinsi Gorontalo; dan 3) Jumriah (2010) Persepsi Siswa Terhadap Pembelajaran Pendidikan Agama Islam pada SMA Negeri 1 Sengkang Kabupaten Wajo. Riset-riset ini menekankan strategi dan metode pembelajaran membantu guru mengelola proses pembelajaran menjadi efektif. 


\section{Macam-macam Strategi Pembelajaran}

Berbagai macam strategi pembelajaran menurut para ahli pendidikan, antara lain, Sanjaya (2008: 299) menyebutkan ada tiga macam yaitu Strategi Pembelajaran Ekspositori, Strategi Pembelajaran Inkuiri, dan Strategi Pembelajaran Kooperatif. Hamruni (2012: 71) menambahkan dua macam selain itu yaitu Strategi Pembelajaran Berbasis Masalah dan Strategi Pembelajaran Kontekstual.

1. Strategi Pembelajaran Ekspositori

Definisi strategi pembelajaran ekspositori sebagaimana dikemukakan Sanjaya dan Hamruni. Sanjaya (2008: 299) mengemukakan bahwa strategi pembelajaran ekspositori merupakan bentuk dari pendekatan pembelajaran yang berorientasi kepada guru, sebab dalam strategi ini guru memegang peran yang sangat dominan. Hamruni (2012: 73) menjelaskan bahwa strategi pembelajaran ekspositori menekankan kepada proses penyampaian materi secara verbal dari seorang guru kepada sekelompok peserta didik dengan maksud agar peserta didik dapat menguasai materi pelajaran secara optimal.

Dalam praktiknya, kegiatan pembelajaran lebih didominasi guru (teacher centered learning), peserta didik diposisikan pada kondisi menerima informasi dari guru tanpa memberi peluang kepada peserta didik melakukan aktivitas pikir dan olah materi secara kritis.

2. Strategi Pembelajaran Inkuiri

Strategi pembelajaran inkuiri adalah kegiatan pembelajaran yang menekankan pada proses berpikir secara kritis dan analitis untuk mencari dan menemukan sendiri jawaban yang sudah pasti dari suatu masalah yang dipertanyakan (Sanjaya, 2008: 196). Pendapat senada, oleh Uno (2009: 30) menyatakan bahwa strategi pembelajaran inkuiri menekankan pada proses mental dan proses berpikir dengan memanfaatkan segala potensi yang dimiliki setiap individu secara optimal.

Dalam praktiknya, kegiatan peserta didik lebih dominan, sehingga dikatakan strategi yang berpusat pada peserta didik (student centered learning). Peran guru adalah sebagai pembimbing dan fasilitator. 
3. Strategi Pembelajaran Kontekstual

Strategi pembelajaran kontekstual adalah suatu konsepsi yang membantu guru mengaitkan konten mata pelajaran dengan situasi dunia nyata dan memotivasi peserta didik membuat hubungan antara pengetahuan dan penerapannya dalam kehidupan mereka sebagai anggota keluarga, warga negara, dan tenaga kerja (Suprihatiningrum, 2013: 178). Kajian sebelumnya, Kunandar (2008: 293) menyatakan, strategi pembelajaran kontekstual merupakan konsep belajar yang beranggapan bahwa anak akan belajar lebih baik jika lingkungan diciptakan secara alamiah, bekerja dan mengalami sendiri apa yang dipelajarinya, bukan sekedar mengetahuinya.

4. Strategi Pembelajaran Berbasis Masalah

Nata (2009: 243) mendefinisikan pembelajaran berbasis masalah adalah strategi pembelajaran yang memperhadapkan peserta didik pada berbagai masalah yang dihadapi dalam kehidupannya. Kunandar (2008: 3030) menyimpulkan bahwa strategi pembelajaran berbasis masalah menggunakan masalah dunia nyata sebagai suatu konteks bagi peserta didik untuk belajar tentang cara berpikir kritis dan keterampilan pemecahan masalah, serta untuk memperoleh pengetahuan dan konsep yang esensial dari materi pelajaran. Jadi strategi pembelajaran ini, menjadikan masalah sebagai titik tolak pembahasan untuk dianalisis dan disintesis dalam usaha mencari pemecahan atau jawabannya oleh peserta didik itu sendiri.

5. Strategi Pembelajaran Kooperatif

Kunandar (2008: 359) mendefinisikan strategi pembelajaran kooperatif adalah strategi yang secara sadar dan sengaja mengembangkan interaksi yang saling asuh antarpeserta didik, melibatkan sejumlah peserta didik dalam kelompok-kelompok kecil, tingkat kemampuannya berbeda untuk menghindari ketersinggungan dan kesalahpahaman yang dapat menimbulkan permusuhan. 


\section{Krisis Akhlak}

\section{Pengertian dan Penyebab Krisis akblak}

Kata krisis berarti kemelut, masa gawat, suasana genting, keadaan merosot (Partanto, 2001: 379). Kata akhlak berarti budi pekerti, tingkah laku, perangai (Partanto, 2001: 14). Ash Shiddieqy (1998: 63) mendefinisikan akhlak yaitu perangai yang tercermin pada tutur kata, tingkah laku, dan sikap. Nata (2010: 203)mendukung pendapat ini. Akhlak yang baik akan membuahkan amal yang baik. Sebaliknya akhlak yang buruk akan menghasilkan pekerjaan yang buruk pula. Krisis akhlak dikonotasikan dengan kemerosotan akhlak. Akhlak bisa baik atau buruk tergantung kepada tata nilai yang dipakai sebagai landasannya, meskipun secara sosiologis masyarakat Indonesia memaknai kata akhlak sudah mengandung konotasi baik.

Krisis akhlak semula hanya menerpa sebagian kecil elit politik dan birokrasi, kini telah menjalar kepada masyarakat luas, bahkan telah merambah pada kalangan peserta didik. Krisis akhlak pada kaum elit terlihat adanya penyelewengan jabatan, korupsi, selingkuh, fitnah, menjilat, dan sebagainya. Krisis akhlak yang menimpa sebagian masyarakat umum terlihat pada sikap merampas hak orang lain, pelecehan seks, anarkis, main hakim sendiri, menyogok, dan sebagainya. Sedangkan krisis akhlak yang menimpa kalangan peserta didik berkenaan dengan ulah sebagian mereka yang sukar dikendalikan, misalnya tawuran pelajar, minuman keras, pergaulan bebas, balapan liar, pulang larut malam, menyontek kunci jawaban ujian nasional (UN), kurang menghargai guru atau menghargainya hanya di sekolah, membolos, merokok di sekolah, dan sebagainya. Berbagai krisis tersebut merupakan indikasi dari kemerosotan akhlak. Membuktikan bahwa bangsa Indonesia yang tadinya tergolong berbudi pekerti luhur, menjadi sirna (Daulay, 2004: 217).

Secara umum penyebab krisis akhlak karena beberapa faktor di antaranya adalah: Pertama, longgarnya pegangan agama menyebabkan hilangnya pengontrol diri. Akibatnya, manusia dapat berbuat sesuka hati dalam melakukan pelanggaran tanpa ada yang menegur; Kedua, pembinaan moral yang dilakukan orangtua, 
sekolah, dan masyarakat kurang efektif; Ketiga, derasnya arus budaya hidup materialistik, hedonistik, dan sekuleristik; dan Keempat, belum adanya kemauan yang sungguh-sungguh dari pemerintah untuk melakukan pembinaan akhlak bangsa (Nata, 2009: 224).

\section{Upaya Antisipasi Krisis Akblak}

Upaya menegakkan akhlak mulia bangsa merupakan suatu keharusan mutlak, sebab kemampuan suatu bangsa untuk bertahan hidup ditentukan oleh sejauhmana rakyat dari bangsa tersebut menjunjung tinggi nilai-nilai akhlak dan moral (al Munawar, 2005: 25). Pada tataran pembinaan keagamaan di sekolah, perlu dilakukan upaya antisipasi terjadinya krisis akhlak pada peserta didik, antara lain adalah:

Pertama, menciptakan suasana religius di sekolah. Untuk mewujudkannya dilakukan pendekatan pembiasaan, pendekatan keteladanan, dan pendekatan persuasif (Muhaimin, 2012: 64).

Kedua, pembinaan keagamaan melalui program ekstrakurikuler. Program ekstrakurikuler merupakan upaya menyiasati kekurangan jam belajar PAI yang hanya dialokasikan 2 jam pelajaran perminggu. Melalui kegiatan ekstrakurikuler peserta didik dapat melakukan praktik-praktik ibadah misalnya pesantren kilat, latihan dakwah, latihan nasyid, baca puisi keagamaan, dan lebih menarik apabila diputarkan film/video yang bernuansa semangat islami. Tujuannya adalah penguatan nilai-nilai agama yang mereka sudah pahami melalui kegiatan intrakurikuler.

Ketiga, menjalin keterpaduan dengan orang tua peserta didik. Orang tua sebagai pendidik dalam lingkungan keluarga harus berupaya menciptakan lingkungan yang kondusif bagi pembentukan akhlak anak-anaknya. Elmubarok (2009: 95) menyatakan, keluarga dengan segala kekhasannya memiliki corak pendidikan yang berbeda dari sekolah. Pendidikan dalam keluarga tumbuh dari kesadaran moral sejati antarorang tua dan anak.

Keempat, guru PAI menjalin sinergi dengan guru non-PAI. Pembinaan akhlak peserta didik tidak hanya tanggung jawab guru PAI. Pelibatan guru lainnya mesti ditumbuhkembangkan 
dengan cara menjalin interaksi, integrasi, dan sinkronisasi secara berkesinambungan. Muhaimin (2012: 24) menekankan seharusnya para guru agama bekerja sama dengan guru-guru non-agama dalam pekerjaan mereka sehari-hari. Pendapat senada oleh Nata (2010: 209) bahwa pendidikan moral bukan hanya menjadi tanggung jawab guru agama, melainkan menjadi tanggung jawab seluruh guru.

\section{Metode Penelitian}

Penelitian ini merupakan studi deskriptif kuantitatif yang bersifat expost facto. Subjek penelitian ini adalah guru-guru PAI pada enam SMA Negeri di Palopo berjumlah 16 orang. Sedangkan objek penelitian ini adalah strategi pembelajaran yang diterapkan oleh guru PAI berimplikasi terhadap upaya antisipasi krisis akhlak peserta didik. Sampel guru berjumlah 16 orang dijadikan sampel jenuh. Sedangkan sampel untuk peserta didik diambil satu kelas dari setiap SMA Negeri di Palopo, sehingga diperoleh jumlah sampel sebanyak 150 orang.

Data dikumpulkan menggunakan teknik angket, yaitu mengedarkan instrumen angket kepada guru PAI berisi 56 item pernyataan untuk memeroleh data tentang penerapan strategi pembelajaran. Kepada peserta didik diberikan instrument angket berisi 56 item pernyataan untuk memeroleh data tentang upaya yang dilakukan guru PAI mengantisipasi terjadinya krisis akhlak pada peserta didik. Riset pustaka juga dijadikan landasan teoretis dalam penelitian ini.

Teknik angket menggunakan skala Likert berupa pernyataan tentang variabel penelitian yang menggunakan empat alternatif jawaban, yaitu sangat sering (SS), sering (S), kadang-kadang (KK), dan tidak pernah (TP). Teknik analisis data yang digunakan adalah statistik deskriptif yaitu teknik yang digunakan untuk mendeskripsikan data sampel (Sugiyono, 2011: 147), berdasarkan nilai tertinggi, nilai terendah, nilai rata-rata, dan tabel distribusi frekuensi, guna menentukan ukuran persentase: sangat tinggi (ST), tinggi (T), rendah (R), dan sangat rendah (SR). Analisis statistik deskriptif dimaksudkan untuk menggambarkan penerapan strategi pembelajaran guru PAI (variabel X), dan upaya antisipasi kerisis 
akhlak peserta didik (variabel Y). Uji korelasional digunakan untuk menggambarkan keterkaitan antara dua variabel. Uji signifikansi digunakan untuk menggambarkan koefisien determinasi seberapa besar variabel $\mathrm{X}$ berkontribusi pada variabel $\mathrm{Y}$.

\section{Analisis}

\section{Deskripsi Lokasi Penelitian}

Lokasi penelitian ini adalah pada enam SMA Negeri di kota Palopo, letaknya kurang lebih $380 \mathrm{Km}$ dari kota Makassar provinsi Sulawesi Selatan. Deskripsi jumlah guru sebagai berikut:

\section{Tabel 1}

\section{Jumlah Guru pada 6 SMA Negeri di Palopo}

\begin{tabular}{|c|c|c|c|c|}
\hline \multirow{2}{*}{ No. } & \multirow{2}{*}{ Nama Sekolah } & \multicolumn{2}{|c|}{ Jenis Guru } & \multirow{2}{*}{ Jumlah } \\
\hline & & Guru PAI & Guru non-PAI & \\
\hline 1 & SMA Negeri 1 & 3 & 65 & 68 \\
\hline 2 & SMA Negeri 2 & 3 & 52 & 55 \\
\hline 3 & SMA Negeri 3 & 3 & 50 & 53 \\
\hline 4 & SMA Negeri 4 & 3 & 50 & 53 \\
\hline 5 & SMA Negeri 5 & 2 & 44 & 46 \\
\hline \multirow[t]{2}{*}{6} & SMA Negeri 6 & 2 & 40 & 42 \\
\hline & Jumlah & 16 & 301 & 317 \\
\hline
\end{tabular}

Sumber data: Hasil olah data jumlah guru pada 6 SMA Negeri di Palopo, dokumentasi, 2013.

Sedangkan deskripsi jumlah peserta didik sebagai berikut:

\section{Tabel 2}

Jumlah Peserta Didik pada 6 SMA Negeri di Palopo

\begin{tabular}{llllll}
\hline No. & Nama SMA & Jumlah & \multicolumn{2}{c}{ Jenis Kelamin } & Jumlah \\
& & Kelas & L & $\mathbf{P}$ & \\
\hline 1 & SMAN 1 & 30 & 370 & 551 & 921 \\
2 & SMAN 2 & 27 & 303 & 512 & 815
\end{tabular}




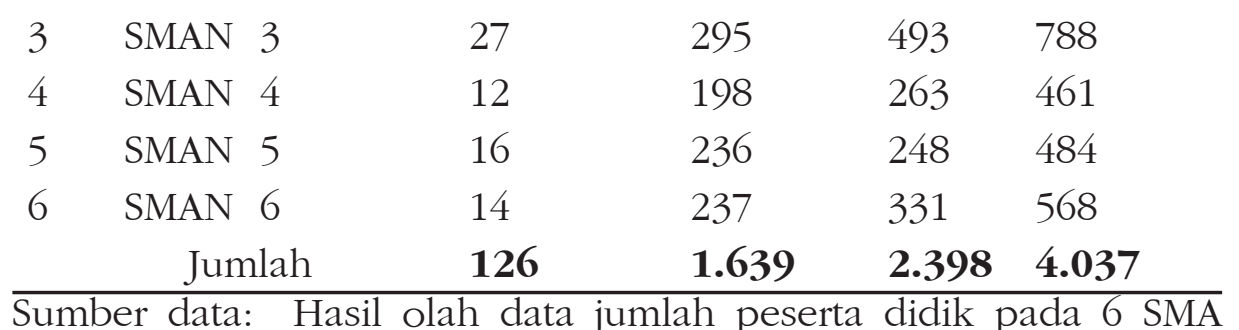
Negeri di Palopo, dokumentasi, 2013.

\section{Penerapan Strategi Pembelajaran oleb Guru Pendidikan Agama Islam}

Tugas pokok guru di sekolah adalah melaksanakan pembelajaran secara profesional sesuai dengan bidang tugasnya. Pelaksanaan proses pembelajaran akan efektif apabila guru memiliki kompetensi dalam memilih dan menerapkan strategi pembelajaran secara tepat. Ada lima macam strategi pembelajaran yang bisa dipilih guru dalam pelaksanaan pembelajaran, yaitu strategi pembelajaran ekspositori, strategi pembelajaran inkuiri, strategi pembelajaran kooperatif, strategi pembelajaran berbasis masalah, dan strategi pembelajaran kontekstual. Uno (2011: 4) menyatakan, dalam memilih strategi pembelajaran selayaknya didasari pada berbagai pertimbangan sesuai dengan situasi, kondisi, dan lingkungan yang akan dihadapi. Ada tiga macam pertimbangan yang diajukan yaitu: a) rumusan tujuan pembelajaran yang telah ditetapkan; b) kebutuhan dan karakteristik peserta didik yang dihadapi; dan c) jenis materi pelajaran yang akan dikomunikasikan.

Untuk memeroleh data tentang penerapan kelima macam strategi pembelajaran tersebut oleh guru PAI maka peneliti buatkan instrumen angket penelitian sebanyak 56 item sesuai dengan indikator dari pada strategi pembelajaran itu. Instrumen angket diberikan kepada guru PAI yang berjumlah 16 orang. Untuk mengetahui kategori penerapannya, apakah kategori sangat sering (SS), sering (S), kadangkadang (KK) atau tidak pernah (TP) dapat dilihat pada akumulasi hasil analisis data angket item 1-56. Hasil analisis data hasil angket tentang penerapan strategi pembelajaran oleh guru PAI pada SMA Negeri di Palopo, disajikakan dalam bentuk tabel sebagai berikut. 


\section{Tabel 3}

Akumulasi Data Hasil Penelitian Tentang Penerapan Strategi Pembelajaran pada SMA Negeri di Palopo

\begin{tabular}{|c|c|c|c|c|c|c|}
\hline \multirow{2}{*}{$\begin{array}{l}\text { No. } \\
\text { Indikator }\end{array}$} & \multirow{2}{*}{$\begin{array}{c}\text { Jenis Strategi } \\
\text { Pembelajaran (SP) }\end{array}$} & \multicolumn{4}{|c|}{ Kategori Jawaban Responden } & \multirow[t]{2}{*}{ Skor } \\
\hline & & SS & $\mathbf{S}$ & KK & $\mathbf{T P}$ & \\
\hline 1. & SP. 1. 1.1 & 9 & 5 & 2 & 0 & 55 \\
\hline 2. & SP. 1. 1.2 & 8 & 4 & 2 & 2 & 50 \\
\hline 3. & SP. 1. 1.3 & 7 & 4 & 5 & 0 & 50 \\
\hline 4. & SP. 1. 1.4 & 10 & 3 & 3 & 0 & 55 \\
\hline 5. & SP. 1. 2.1 & 6 & 6 & 4 & 0 & 55 \\
\hline 6. & SP. 1. 2.2 & 12 & 2 & 2 & 0 & 58 \\
\hline 7. & SP. 1. 2.3 & 2 & 3 & 11 & 0 & 39 \\
\hline 8. & SP. 1. 3. 1 & 1 & 2 & 11 & 2 & 34 \\
\hline 9. & SP. 1. 3. 2 & 3 & 10 & 3 & 0 & 38 \\
\hline 10. & SP. 1. 3.3 & 3 & 9 & 4 & 0 & 47 \\
\hline 11. & SP. 1. 4.1 & 4 & 9 & 3 & 0 & 49 \\
\hline 12. & SP. 1. 4. 2 & 4 & 12 & 0 & 0 & 52 \\
\hline 13. & SP. 1. 5.1 & 0 & 8 & 6 & 2 & 38 \\
\hline 14. & SP. 1. 5.2 & 1 & 13 & 2 & 0 & 47 \\
\hline 15. & SP. 2. 1.1 & 4 & 10 & 2 & 0 & 40 \\
\hline 16. & SP. 2. 2. 1 & 2 & 10 & 3 & 1 & 45 \\
\hline 17. & SP. 2. 2. 2 & 1 & 4 & 11 & 0 & 38 \\
\hline 18. & SP. 2. 2. 3 & 1 & 9 & 3 & 3 & 40 \\
\hline 19. & SP. 2. 3. 1 & 1 & 9 & 4 & 2 & 41 \\
\hline 20. & SP. 2. 3. 2 & 2 & 9 & 5 & 0 & 45 \\
\hline 21. & SP. 2. 4.1 & 3 & 9 & 4 & 0 & 47 \\
\hline 22. & SP. 2. 5.1 & 2 & 10 & 2 & 2 & 44 \\
\hline 23. & SP. 2. 5.2 & 0 & 12 & 4 & 0 & 44 \\
\hline 24. & SP. 2. 6.1 & 2 & 12 & 1 & 1 & 47 \\
\hline 25. & SP. 2. 6.2 & 0 & 10 & 4 & 2 & 40 \\
\hline 26. & SP. 3. 1.1 & 0 & 14 & 2 & 0 & 46 \\
\hline 27. & SP. 3. 1.2 & 2 & 12 & 2 & 0 & 48 \\
\hline 28. & SP. 3. 1.3 & 1 & 11 & 3 & 1 & 44 \\
\hline 29. & SP. 3. 2. 1 & 3 & 7 & 4 & 2 & 43 \\
\hline
\end{tabular}




\begin{tabular}{|c|c|c|c|c|c|}
\hline 30. & SP. 3. 2. 2 & 4 & 10 & 1 & 1 \\
\hline 31. & SP. 3. 2.3 & 2 & 12 & 2 & 0 \\
\hline 32. & SP. 3. 2.4 & 2 & 12 & 2 & 0 \\
\hline 33. & SP. 3. 2.5 & 1 & 13 & 2 & 0 \\
\hline 34. & SP. 3. 3. 1 & 0 & 4 & 10 & 2 \\
\hline 35. & SP. 3. 3. 2 & 1 & 12 & 3 & 0 \\
\hline 36. & SP. 3. 3.3 & 0 & 14 & 2 & 0 \\
\hline 37. & SP. 3. 4. 1 & 0 & 13 & 3 & 0 \\
\hline 38. & SP. 3. 4. 2 & 6 & 10 & 0 & 0 \\
\hline 39. & SP. 4. 1. 1 & 3 & 10 & 3 & 0 \\
\hline 40. & SP. 4. 1. 2 & 6 & 10 & 0 & 0 \\
\hline 41. & SP. 4. 1. 3 & 3 & 12 & 1 & 0 \\
\hline 42. & SP. 4. 1. 4 & 5 & 11 & 0 & 0 \\
\hline 43. & SP. 4. 2.1 & 3 & 9 & 3 & 1 \\
\hline 44. & SP. 4. 2. 2 & 0 & 10 & 4 & 2 \\
\hline 45. & SP. 4. 2. 3 & 2 & 14 & 0 & 0 \\
\hline 46. & SP. 4. 2.4 & 2 & 12 & 1 & 1 \\
\hline 47. & SP. 4. 2. 5 & 0 & 8 & 6 & 2 \\
\hline 48. & SP. 5.11 & 4 & 8 & 2 & 2 \\
\hline 49. & SP. 5. 2. 1 & 4 & 10 & 2 & 0 \\
\hline 50. & SP. 5. 3. 1 & 4 & 12 & 0 & 0 \\
\hline 51. & SP. 5. 4. 1 & 2 & 11 & 2 & 1 \\
\hline 52. & SP. 5. 5.1 & 2 & 12 & 2 & 0 \\
\hline 53. & SP. 5. 6. 1 & 3 & 9 & 3 & 1 \\
\hline 54. & SP. 5. 7.1 & 1 & 14 & 1 & 0 \\
\hline 55. & SP. 5. 8. 1 & 4 & 12 & 0 & 0 \\
\hline 56. & SP. 5.9. 1 & 2 & 9 & 4 & 1 \\
\hline
\end{tabular}

Jumlah

2596

Sumber data: Hasil analisis angket untuk guru PAI item 1-56

Akumulasi hasil penelitian tentang penerapan strategi pembelajaran oleh guru PAI pada tabel di atas, ditemukan skor sebesar 2596 sedangkan skor ideal (kriterium) untuk seluruh item angket sebesar $4 \times 16 \times 56=3584$ (jika 16 responden memilih kategori sangat sering (SS) pada 56 item angket). Jadi $2596: 56=$ $46,36: 16=2,90$ lebih dekat pada skor 3 dengan kategori sering (S), 
dan persentase sebesar $(2596: 3584) \times 100 \%=72,43 \%$ berada pada interval 70 sampai 84 dengan kategori tinggi (T), sehingga dapat disimpulkan bahwa strategi pembelajaran diterapkan oleh guru mata pelajaran PAI pada 6 SMA Negeri di Palopo meliputi strategi pembelajaran ekspositori, strategi pembelajaran inkuiri, strategi pembelajaran kooperatif, strategi pembelajaran berbasis masalah, dan strategi pembelajaran kontekstual dengan kategori tinggi (T) dan intensitas sering $(S)$.

Hasil analisis akumulasi tersebut selanjutnya dianalisis secara parsial terhadap penerapan kelima macam strategi pembelajaran, diketahui persentase penerapan setiap strategi pembelajaran tersebut seperti pada tabel berikut.

\section{Tabel 4 \\ Persentase Penerapan Kelima Macam Strategi Pembelajaran oleh Guru PAI pada SMA Negeri di Palopo}

\begin{tabular}{cll}
\hline No. & \multicolumn{1}{c}{$\begin{array}{c}\text { MacamStrategi } \\
\text { Pembelajaran }\end{array}$} & Persentase (\%)Penerapan \\
\hline 1. & SP. Ekspositori & 74,44 \\
2. & SP. Inkuiri & 66,52 \\
3. & SP. Kooperatif & 71,88 \\
4. & SP. Berbasis Masalah & 73,96 \\
5. & SP. Kontekstual & 75 \\
\hline
\end{tabular}

Data pada tabel di atas, diketahui bahwa dari kelima macam strategi pembelajaran yang diterapkan oleh guru PAI pada SMA Negeri di Palopo, Strategi Pembelajaran Kontekstual memeroleh persentase lebih tinggi yaitu sebesar 75\% dibanding dengan macam strategi pembelajaran lainnya. Artinya, indikator dari pada Strategi Pembelajaran Kontekstual lebih sering diterapkan oleh guru PAI daripada strategi pembelajaran lainnya.

Penerapan strategi pembelajaran tersebut berimplikasi pada proses dan hasil belajar PAI yang dicapai. Pada konteks hasil belajar mata pelajaran PAI semester gasal 2013/2014, peneliti memeroleh data dokumentasi nilai dari guru PAI. Hasil olah dan analisis data 
nilai tersebut dideskripsikan pada tabel berikut.

\section{Table 5}

Nilai Hasil Belajar Mata Pelajaran Pendidikan Agama Islam pada SMA Negeri di Palopo

\begin{tabular}{lll}
\hline No. & Sekolah & Rata-rata \\
\hline 1 & SMA Negeri 1 Palopo & 88,30 \\
2 & SMA Negeri 2 Palopo & 88,03 \\
3 & SMA Negeri 3 Palopo & 87,26 \\
4 & SMA Negeri 4 Palopo & 88,80 \\
5 & SMA Negeri 5 Palopo & 88,18 \\
6 & SMA Negeri 6 Palopo & 84,28 \\
Rata-rata & & 87,475 \\
\hline
\end{tabular}

Hasil belajar ini mendeskripsikan prestasi belajar yang telah dicapai melampaui nilai keriteria ketuntasan minimum (KKM), ini berarti ada implikasi dari pada strategi pembelajaran yang diterapkan oleh guru PAI.

Upaya Antisipasi Krisis Akblak Peserta Didik pada SMA Negeri di Palopo

Berpijak pada fenomena perilaku di masyarakat di era modernisasi kini maka pembinaan akhlak pada peserta didik di sekolah menjadi urgen dilakukan. Karena itu perlu dilakukan upaya sebagai tindakan antisipasi terjadinya krisis akhlak pada peserta didik. Upaya tersebut adalah melalui pendidikan akhlak, mengatasi krisis akhlak, optimalisasi peran guru PAI, dan pembelajaran akhlak di SMA.

Untuk memeroleh data tentang penerapan keempat macam upaya tersebut oleh guru PAI maka peneliti buatkan instrumen angket penelitian sebanyak 56 item sesuai dengan indikatornya masingmasing. Instrumen angket tersebut diberikan kepada peserta didik berjumlah 150 orang. Untuk mengetahui kategori penerapannya, apakah kategori sangat sering (SS), sering (S), kadang-kadang (KK) atau tidak pernah (TP), dapat dilihat pada akumulasi data hasil 
analisis angket item 1-56 tentang upaya yang dilakukan oleh guru PAI dalam mengantisipasi krisis akhlak peserta didik pada SMA Negeri di Palopo sebagai berikut.

\section{Tabel 6}

Akumulasi Data Hasil Penelitian Tentang Upaya Guru PAI dalam Mengantisipasi Krisis Akhlak Peserta Didik pada SMA Negeri di Palopo

\begin{tabular}{|c|c|c|c|c|c|c|}
\hline \multirow[t]{2}{*}{$\begin{array}{c}\text { No. } \\
\text { Indikator }\end{array}$} & \multirow{2}{*}{$\begin{array}{c}\text { Jenis Upaya } \\
\text { Antisipasi (UA) }\end{array}$} & \multicolumn{4}{|c|}{$\begin{array}{l}\text { Kategori Jawaban } \\
\text { Responden }\end{array}$} & \multirow[t]{2}{*}{ Skor } \\
\hline & & SS & $\mathbf{S}$ & KK & $\mathbf{T P}$ & \\
\hline 1. & UA. 1.1 & 140 & 8 & 3 & 0 & 590 \\
\hline 2. & UA. 1.2 & 150 & 0 & 1 & 0 & 602 \\
\hline 3. & UA. 1.3 & 100 & 50 & 1 & 0 & 552 \\
\hline 4. & UA. 1.4 & 145 & 5 & 1 & 0 & 597 \\
\hline 5. & UA. 1.5 & 150 & 0 & 1 & 0 & 602 \\
\hline 6. & UA. 1.6 & 146 & 3 & 2 & 0 & 597 \\
\hline 7. & UA. 1.7 & 135 & 12 & 4 & 0 & 584 \\
\hline 8. & UA. 2.1 & 150 & 0 & 1 & 0 & 602 \\
\hline 9. & UA. 2.2 & 125 & 23 & 3 & 0 & 575 \\
\hline 10. & UA. 2.3 & 150 & 0 & 1 & 0 & 602 \\
\hline 11. & UA. 2. 4 & 135 & 14 & 2 & 0 & 586 \\
\hline 12. & UA. 2.5 & 150 & 0 & 1 & 0 & 602 \\
\hline 13. & UA. 3.1 & 139 & 9 & 3 & 0 & 589 \\
\hline 14. & UA. 3.2 & 139 & 8 & 4 & 0 & 588 \\
\hline 15. & UA. 3.3 & 150 & 1 & 0 & 0 & 603 \\
\hline 16. & UA. 3.4 & 100 & 41 & 10 & 0 & 543 \\
\hline 17. & UA. 3.5 & 135 & 10 & 6 & 0 & 582 \\
\hline 18. & UA. 3.6 & 140 & 6 & 5 & 0 & 588 \\
\hline 19. & UA. 3.7 & 125 & 20 & 6 & 0 & 572 \\
\hline 20. & UA. 3.8 & 100 & 30 & 21 & 0 & 532 \\
\hline 21. & UA. 3.9 & 116 & 30 & 5 & 0 & 564 \\
\hline 22. & UA. 4.1 & 140 & 7 & 4 & 0 & 589 \\
\hline
\end{tabular}




\begin{tabular}{|c|c|c|c|c|c|c|}
\hline 23. & UA. 4.2 & 136 & 15 & 0 & 0 & 589 \\
\hline 24. & UA. 4.3 & 141 & 8 & 2 & 0 & 592 \\
\hline 25. & UA. 4.4 & 145 & 4 & 2 & 0 & 596 \\
\hline 26. & UA. 4.5 & 146 & 0 & 5 & 0 & 594 \\
\hline 27. & UA. 4.6 & 140 & 10 & 1 & 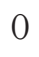 & 592 \\
\hline 28. & UA. 4.7 & 136 & 9 & 6 & 0 & 583 \\
\hline 29. & UA. 4.8 & 136 & 7 & 8 & 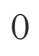 & 581 \\
\hline 30. & UA. 4.9 & 132 & 10 & 9 & 0 & 576 \\
\hline 31. & UA. 4. 10 & 134 & 10 & 7 & 0 & 580 \\
\hline 32. & UA. 4. 11 & 132 & 11 & 8 & 0 & 577 \\
\hline 33. & UA. 4.12 & 132 & 12 & 7 & ) & 578 \\
\hline 34. & UA. 4.13 & 130 & 14 & 7 & 0 & 576 \\
\hline 35. & UA. 4.14 & 135 & 12 & 4 & 0 & 584 \\
\hline 36. & UA. 4.15 & 135 & 13 & 3 & 0 & 585 \\
\hline 37. & UA. 4.16 & 124 & 12 & 15 & 0 & 562 \\
\hline 38. & UA. 4.17 & 136 & 10 & 5 & ) & 584 \\
\hline 39. & UA. 4. 18 & 150 & 0 & 1 & 0 & 602 \\
\hline 40. & UA. 4. 19 & 143 & 6 & 2 & 0 & 594 \\
\hline 41. & UA. 4. 20 & 144 & 4 & 3 & 0 & 594 \\
\hline 42. & UA. 4. 21 & 131 & 15 & 5 & 0 & 579 \\
\hline 43. & UA. 4. 22 & 120 & 21 & 10 & 0 & 563 \\
\hline 44. & UA. 4.23 & 136 & 8 & 7 & 0 & 582 \\
\hline 45. & UA. 4. 24 & 140 & 8 & 3 & 0 & 590 \\
\hline 46. & UA. 4.25 & 148 & 0 & 3 & 0 & 598 \\
\hline 47. & UA. 4.25 & 147 & 4 & 0 & 0 & 600 \\
\hline 48. & UA. 4.27 & 150 & 1 & 0 & 0 & 603 \\
\hline 49. & UA. 4. 28 & 149 & 1 & 1 & 0 & 601 \\
\hline 50. & UA. 4. 29 & 100 & 40 & 11 & 0 & 542 \\
\hline 51. & UA. 4.30 & 150 & 1 & 0 & 0 & 603 \\
\hline 52. & UA. 4.31 & 146 & 3 & 2 & 0 & 597 \\
\hline 53. & UA. 4.32 & 100 & 46 & 5 & 0 & 548 \\
\hline 54. & UA. 4.33 & 136 & 10 & 5 & 0 & 584 \\
\hline 55. & UA. 4.34 & 96 & 40 & 15 & 0 & \\
\hline
\end{tabular}


$\begin{array}{lllllll}\text { 56. } & \text { UA. } 4.35 & 50 & 100 & 1 & 0 & 502\end{array}$

Jumlah

Sumber data: hasil analisis angket untuk peserta didik item 1-56.

Akumulasi data hasil penelitian tentang upaya antisipasi krisis akhlak peserta didik pada tabel di atas menunjukkan bahwa terdapat skor sebesar 32586 sedangkan skor ideal (kriterium) untuk seluruh item sebesar 4 x 151 x $56=33824$ (jika sejumlah 151 responden memilih kategori sangat sering (SS) pada sejumlah 56 item angket). Jadi $32586: 56=581,89: 151=3,85$ yang lebih dekat pada skor 4 dengan kategori sangat sering (SS) dengan persentase sebesar (32586 : 33824) x 100\% = 96,34\% yang berada pada interval 85 sampai dengan 100 dengan kategori sangat tinggi (ST), sehingga dapat disimpulkan bahwa guru PAI melakukan upaya mengantisipasi krisis akhlak peserta didik dengan kategori sangat tinggi (ST) dan intensitas sangat sering (SS).

Hasil analisisi akumulasi tersebut selanjutnya dianalisis secara parsial terhadap keempat upaya antisipasi krisis akhlak peserta didik pada SMA Negeri di Palopo, diketahui persentase penerapannya seperti pada tabel berikut.

\section{Tabel 6}

Persentase Penerapan Keempat Macam Upaya Antisipasi Krisis Akhlak Peserta Didik

\begin{tabular}{lll}
\hline No. & Macam Upaya Antisipasi (UA) & Persentase (\%) Penerapan \\
\hline 1. & UA. Pendidikan Akhlak & 97,54 \\
2. & UA. Mengatasi Krisis Akhlak & 98,25 \\
3. & UA. Optimalisasi Peran Guru & 94,94 \\
& Pendidikan Agama Islam & \\
4. & UA. Pembelajaran Akhlak & 96,19 \\
\hline
\end{tabular}

Data pada tabel di atas diketahui bahwa dari keempat macam upaya antisipasi krisis akhlak peserta didik pada SMA Negeri di Palopo yang diterapkan oleh guru Pendidikan Agama Islam maka upaya Mengatasi Krisis Akhlak memeroleh persentase lebih tinggi, yaitu sebesar 98,25\% dibanding dengan upaya lainnya. Artinya, 
upaya mengatasi krisis akhlak dengan beberapa indikatornya sangat sering dilakukan oleh guru PAI dalam pelaksanaan pembelajaran Pendidikan Agama Islam pada SMA Negeri di Palopo.

\section{Implikasi Strategi Pembelajaran Terhadap Upaya Antisipasi Krisis Akblak}

Hasil analisis tentang penerapan strategi pembelajaran pada SMA Negeri di Palopo kategori tinggi dengan intensitas sering, dan hasil analisis tentang upaya guru dalam antisipasi krisis akhlak peserta didik kategori sangat tinggi dengan intensitas sangat sering, menjadi tolak ukur melihat ada tidaknya korelasi antara kedua variabel tersebut.

Hasil analisis koefisien korelasi ditemukan $r_{\text {hitung }}$ sebesar 0,167 $<\mathrm{r}_{\text {tabel }}=0,254$ (untuk $\mathrm{n}=56$ ) sehingga $\mathrm{H}_{0}$ diterima dan $\mathrm{H}_{1}$ ditolak. Artinya, tidak ada hubungan antara variabel $X$ (penerapan strategi pembelajaran) dengan variabel Y (upaya antisipasi krisis akhlak). Selanjutnya, uji signifikansi ditemukan nilai $\mathrm{t}_{\text {hitung }=} 1,256<\mathrm{t}_{\text {tabel }}=$ 2,021, sehingga $\mathrm{H}_{0}$ yang menyatakan tidak terdapat korelasi yang signifikan antara variabel $\mathrm{X}$ (penerapan strategi pembelajaran) dengan variabel Y (upaya antisipasi krisis akhlak).

Berpijak pada hasil analisis koefisien korelasi dan uji signifikansi tersebut dapat dinyatakan bahwa keberhasilan pembelajaran PAI pada SMA Negeri di Palopo adalah karena guru sering (S) menerapkan strategi pembelajaran dengan intensitas tinggi (T). Demikian halnya, upaya mengantisipasi krisis akhlak peserta didik sangat sering (SS) dilakukan dengan intensitas sangat tinggi (ST). Akan tetapi, penerapan strategi pembelajaran tidak ada implikasinya dengan upaya mengantisipasi krisis akhlak peserta didik pada SMA Negeri di Palopo. Hal ini ditunjukkan oleh koefisien determinasi sangat rendah (SR) yaitu 2,789\%. Artinya terdapat 97,21\% faktor lain yang berimplikasi terhadap upaya antisipasi krisis akhlak peserta didik pada SMA Negeri di Palopo. Faktor lain yang berimplikasi terhadap upaya antisipasi krisis akhlak peserta didik pada SMA Negeri di Palopo adalah faktor psikologis dan fisiologis yang bersumber dari dalam diri peserta didik, dan faktor instrumental dan environmental yang bersumber dari luar diri peserta didik. 


\section{Kesimpulan}

Pertama, di kota Palopo terdapat 6 SMA Negeri. Jumlah guru seluruhnya 317 terdiri atas guru PAI 16 orang dan guru non PAI 301 orang. Hasil belajar pembelajaran PAI dianggap berhasil karena nilai akhir semester ganjil 2013/2014 rata-rata 87,47. Hasil belajar ini sebagai implikasi dari pada guru PAI sering menerapkan strategi pembelajaran dan secara bervariasi. Hal ini dilihat dari hasil analisis statistik ditemukan skor rerata sebesar 2,90 dan persentase sebesar 72,43\%. Kedua, guru PAI pada SMA Negeri di Palopo sangat sering melakukan upaya antisipasi krisis akhlak peserta didik, sehingga peserta didik tidak terjerumus pada krisis akhlak. Hal ini dilihat dari hasil analisis statistik ditemukan skor rerata sebesar 3,85 dan persentase sebesar 96,19\%. Ketiga, penerapan strategi pembelajaran oleh guru PAI tidak signifikan berimplikasi terhadap upaya yang dilakukan untuk antisipasi krisis akhlak peserta didik pada SMA Negeri di Palopo. Hal ini dilihat dari hasil analisis statistik diperoleh $r_{\text {hitung }}=0,167<r_{\text {tabel }}=0,266(n=56)$ pada taraf sifnifikan 5\%. Artinya, tidak ada korelasi yang signifikan antara strategi pembelajaran yang diterapkan guru PAI dengan upaya antisipasi krisis akhlak peserta didik. Kontribusi variabel bebas $(\mathrm{X})$ terhadap variabel terikat $(\mathrm{Y})$ ditentukan dengan uji determinasi sebesar 2,789\%. Artinya, guru PAI menerapkan strategi pembelajaran dengan baik, dan akhlak peserta didik juga baik, tetapi kontribusi strategi pembelajaran terhadap akhlak peserta didik kategori rendah, karena 97,21\% ditentukan oleh variabel lain. 


\section{Daftar Pustaka}

Baki, Nasir A. 2014. Metode Pembelajaran Agama Islam. Yogyakarta: Eja_Publisher.

Daulay, Haidar Putra. 2004. Pendidikan Islam dalam Sistem Pendidikan Nasional di Indonesia. Ed. I, Cet. I; Jakarta: Kencana.

Djamarah, Syaiful Bahri dan Aswan Zain. 2006. Strategi Belajar Mengajar. Cet. III; Jakarta: Rineka Cipta.

Elmubarok, Zaim. 2009. Membumikan Pendidikan Nilai. Cet. II; Bandung: Alfabeta.

Hamruni. 2012. Strategi Pembelajaran. Yogyakarta: Insan Madani.

Kunandar. 2008. Guru Profesional: Implementasi KTSP dan Sukses dalam Sertifikasi Guru. Jakarta: RajaGrafindo Persada.

Muhaimin. 2012. Pengembangan Kurikulum Pendidikan Agama Islam di Sekolah, Madrasah, dan Perguruan Tinggi. Ed. I, Cet. V; Jakarta: Rajawali Pers.

Al Munawar, Said Agil Husin. 2005. Aktualisasi Nilai-nilai Qur'ani dalam Sistem Pendidikan Islam. Cet. II; Jakarta: Ciputat Press.

Nata, Abuddin. 2010. Manajemen Pendidikan Mangatasi Kelemahan Pendidikan Islam di Indonesia. Ed. III, Cet. IV; Jakarta: Kencana. 2009. Perspektif Islam tentang Strategi Pembelajaran. Cet. I; Jakarta: Kencana.

Partanto, Pius A., dan M. Dahlan al Barry. 2001. Kamus Ilmiah Populer. Surabaya, Arloka.

Pimay, Awaluddin. 2005. Paradigma Dakwah Humanis: Strategi dan Metode Dakwah Prof. K. H. Saifuddin Zuhri. Cet. I; Semarang: RaSAIL. 
Republik Indonesia. 2006. Undang-Undang Nomor 20 Tahun 2003 tentang Sistem Pendidikan Nasional. Bandung: Fermana. 2005. Peraturan Pemerintah Nomor 55 Tahun 2007 tentang Pendidikan Agama dan Pendidikan Keagamaan.

Rusman. 2010. Model-Model Pembelajaran Mengembangkan Profesionalisme Guru. Cet. I; Jakarta: RajaGrafindo Persada.

Sabri, Ahmad. 2005. Strategi Belajar Mengajar dan Micro Teaching.

Cet. I; Jakarta: Quantum Teaching.

Sanjaya, Wina. 2008. Strategi Pembelajaran Berorientasi Standar Proses Pendidikan. Jakarta: Kencana Prenada Media Group.

Ash-Shiddiqy, Teungku Muhammad Hasbi. 1998. Al-Islam 1. Cet. I; Semarang: Pustaka Rizki Putra.

Sugiyono. 2011. Metode Penelitian Kuantitatif, Kualitatif dan R\&D. Cet. XIII; Bandung: Alfabeta.

Suprihatiningrum, Jamil. 2013. Strategi Pembelajaran: Teori \& Praktik. Cet. I; Jakarta: Ar-Ruzz Media.

Uno, Hamzah B., dan Nurdin Mohamad. 2011. Belajar dengan Pendekatan PAILKEM. Cet. I; Jakarta: Bumi Aksara.

Wena, Made. 2011. Strategi Pembelajaran Inovatif Kontemporer. Cet. VI; Jakarta: Bumi Aksara.

Jumriah. 2010. Persepsi Siswa Terhadap Pembelajaran Pendidikan Agama Islam pada SMA Negeri 1 Sengkang Kabupaten Wajo. Tesis tidak dipublikasikan. Makassar: Program Pascasarjana Universitas Islam Negeri Alauddin Makassar.

Suhra, Sarifa. 2014. Strategi Guru Pendidikan Agama Islam dalam Mengembangkan Pendidikan Karakter pada Peserta Didik SMA Negeri 1 Watampone. Disertasi tidak dipublikasikan. Makassar: Program Pascasarjana Universitas Islam Negeri Alauddin Makassar. 
Syamsu S.

Yahiji. 2011. Strategi Pembelajaran dalam Meningkatkan Pemahaman Kitab Kuning di Pondok Pesantren Salafiyah Syafi'iyah Randangan Provinsi Gorontalo. Disertasi tidak dipublikasikan. Makassar: Program Pascasarjana Universitas Islam Negeri Alauddin Makassar. 